\title{
On Pia Arke
}

Stefan J onsson

The self-archived postprint version of this journal article is available at Linköping University Institutional Repository (DiVA):

http:// urn.kb.se/ resolve?urn=urn:nbn:se:liu:diva-141969

N.B.: When citing this work, cite the original publication.

J onsson, S., (2017), On Pia Arke, Afterall, (44), 10-20. https:// doi.org/ 10.1086/ 695509

Original publication available at:

https:// doi.org/ 10.1086/695509

Copyright: University of Chicago Press (No Paid Open Access)

http:// www.press.uchicago.edu/ 


\section{On Pia Arke}

\section{By Stefan Jonsson}

Pia Arke’s work reminds Danes and Europeans of a history they never got to know, or were taught not to know, because it happened overseas. It began to be shown and discussed at the beginning of the 1990s, a period when notions of globalisation offered new models for understanding the dynamics of the world and exposed neglected historical and aesthetic issues. Among the most important of these issues were the colonial legacies of Western European states. In this context, Pia Arke's interrogations of the suppressed past of Denmark’s relationship with Greenland began to resonate. The daughter of an Inuit seamstress and a Danish telegraphist, she was born in 1958 in Scoresbysund, or Ittoqqortoormiit, Denmark’s outermost colonial settlement in northeast Greenland. She was from birth entangled in imperial processes that endowed her with split vision and multiple identities. These qualities animated her art already in the 1980s, when she studied at Copenhagen's Royal Academy of Fine Arts, and until her untimely death at the age of 48, when she stood on the threshold of international recognition.

Pia Arke’s work displayed a mesmerising blend of approaches: painting, photography, montage, video, performance and installation art. Her violation of artistic genres was carefully premeditated. A taste for the absurdity of scientific collecting brought her to examine underground vaults - paleontological and ethnographic archives - stuffed with dusty specimens. She made a mockery of all attempts to represent and classify the natives and nature of the Arctic. Solidarity with the silenced victims of history prompted her to reinvent the art of photography, and to strenuously engage with oral history. She deconstructed ethnography, photography, travel writing, history, landscape painting and much more, and 
reassembled their elements into multilayered and ambiguous montages conceived in a spirit of criticality and playfulness.

Her aesthetic strategies targeted what I call the essential trait of global history. ${ }^{1}$ She attributed this trait to the voice and body of a specific female subject. By enacting this subject, on a stage literally balanced on the edge of the Arctic world, she exposed the inner secrets of colonial globalisation and Danish nation building. 'I make the history of colonialism part of my history in the only way I know, namely by taking it personally', she wrote in her book Scorsebysundhistorier: Fotografier, kolonisering og kortlaggning (Stories from

Scoresbysund: Photography, Colonisation and Mapping), completed in 2003. ${ }^{2}$ Taking history personally meant quietly asserting the life story that was hers as an aesthetic vantage point for viewing past and present with a decolonial gaze.

It was a path-breaking gaze on Northern Europe. It evolved within a contracted career marked by periods of intense experimentation. I had the privilege of following this work, beginning in the 1990s, when Pia and I started a long and winding conversation that led to rewarding collaborative projects. At that time, for a critic and writer interested in the aftereffects of colonialism on European culture, Pia’s visual universe was a revelation. In unpredictable ways, her work at once embodied and enriched the theoretical discourse of the period - its notions of hybridity, métissage, third-space subjectivities and subalternity. Pia coined the term 'ethno-aesthetics' to describe the situation in which she found herself trapped as a Greenlandic-Danish artist expected to recycle visual clichés associated with 'Eskimo’ culture. ${ }^{3}$ In other words, she coined the term to point out the prison-house of indigeneity from which she sought to escape. But she also used 'ethno-aesthetics' to designate a context that

\footnotetext{
${ }^{1}$ For further elaboration of this concept, see my 'Disclosing the World Order: Decolonial Gestures in the Artistic Work of Pia Arke’, Third Text, vol.27, no.2, 2013, pp.242-59.

${ }^{2}$ Pia Arke with Stefan Jonsson, Stories from Scoresbysund: Photography, Colonisation and Mapping (trilingual edition in English, Greenlandic and Danish, translations by John Kendal, Jessie Kleeman and Stephen Heilmann), Copenhagen: Kuratorisk Aktion and the Pia Arke Selskabet, 2010, p. 13. Originally published in Danish as Scorsebysundhistorier: Fotografier, kolonisering og kortlceggning, Copenhagen: Borgen forlag, 2003. ${ }^{3}$ P. Arke, Etnoæstetik, Aarhus: Kunsttidskriftet ARK, 1995.
} 
continuously nourished her imagination. Three distinct phases of her career can be identified in retrospect. ${ }^{4}$

\section{II}

The first phase began when Pia, in 1988, decided to construct her own camera-house. Built from pine and plywood and painted bright white, the camera was big enough to stand or lie in. This camera obscura was a container with a small hole at the front. She would climb into it through a small hatch and affix a piece of sheet film on the back wall. She would then uncover the aperture to let incoming light strike the film, and she would remain inside for the full exposure time - usually fifteen to thirty minutes - during which she manipulated the image by partly shading the film to mark it with her body’s ghostly contour.

Pia had this colossal camera shipped to Greenland with the intention of mounting it in all the places in Greenland where she had lived as a child. Her first stop was Nuugaarsuk, in southern Greenland. She captured these surroundings in images that appear like distilled childhood dreams, or extraterrestrial landscapes (Pointen [The Point], 1990). As transportation in Greenland is forbiddingly expensive, she could not afford to complete the project. (Pia’s production budgets were always tight.) However, she used the pinhole camera on the east coast of Denmark (next to the castle where William Shakespeare set Hamlet) for another hypnotic series of photographs, which she called Kronborg-serien (The Kronborg Suite, 1995). Images of the coastline here appear through butterfly shapes that the artist created by placing her arms and torso in front of the film during the exposure. In this way, each image bears traces of the subject who made it.

The superimposition of object and subject of representation provide a general model of Arke’s visual aesthetics. She approached existing accounts and images of Greenland,

\footnotetext{
${ }^{4}$ For a comprehensive presentation of Pia Arke's oeuvre and reproductions of her work, see Kuratorisk Aktion (ed.), TUPILAKOSAURUS: An Incomplete(able) Survey of Pia Arke's Artistic Work and Research, Copenhagen: Kuratorisk Aktion, 2012.
} 
including her own memories, through hermeneutics at once suspicious and restorative retrieving human lives that had been erased from the artefacts and data stored in the archive, and thus exposing the ways in which violence and power masquerade as scientific achievement and progress.

Inuit assistance, knowledge and labour formed the precondition of the exploration and colonisation of Greenland, but their contributions were rarely recorded. In Pia’s darkroom, these lives were rediscovered, redeveloped and subsequently reinserted - always with a hint of humour - into the past and present of Danish-Greenlandic transactions. In this sense, it may be said that Pia situated her work at the limit of world history; her work indicates the limit of historical understanding, and points toward its non-representable exteriority. Usually, too, she invested this place with human agency by marking it by the limit image of a female subject. Frederikke Hansen and Tone Olaf Nielsen, the curators of the first major retrospective of Arke’s work, ${ }^{5}$ have stressed that 'there are myriads of women in Arke’s pictorial universe dressed, undressed, stripped, old, young, dumbstruck, in love. You name it.. ${ }^{6}$

This female subject is situated on a thin edge - between culture and nature, perspective and scenery, camera and landscape. She is strangely endowed with agency. In several of Pia's works she speaks back, in words or gestures. Look at De tre Gratier (The Three Graces, 1993), or at the dolls photographed in Borte med blæsten (Gone with the Wind, 1997), or at the ghostlike self-portraits for which Pia superimposed photographs of herself over the majestic fjord at Nuugaarsuk (Selvportræet [Self-Portrait], 1992). A transparent, almost invisible woman appears, her skin made of the same matter as the landscape; her contours fusing with the geological shapes of plains and mountains. Is she part of the represented

\footnotetext{
${ }^{5}$ Frederikke Hansen and Tone Olaf Nielsen Nilesen, with support from the Pia Arke Society, organized the retrospective exhibition TUPILAKOSAURUS: Pia Arke's Issue with Art, Ethnicity, and Colonialism, 1981-2006. The exhibition was shown at Den Frie Centre of Contemporary Art and the National Museum of Denmark, in Copenhagen January 8 - February 14, 201, at Katuaq - Cultural Centre of Greenland and Greenland's National Museum and Archives, Nuuk, March 5 - April 4, 2010, and Bildmuseet, Umeå, Sweden, June 6 - September 5, 2010.

${ }^{6}$ Quoted in Kuratorisk Aktion, 'Arctic Hysteria: The Greenlandic Woman’s Body as Battlefield’, in ibid., p.73.
} 
motif? Is she generated by the act of representation? She belongs to both orders. To ask for her true identity is pointless.

As for the 'three graces', they first seem to face the camera, apparently accepting their status as exhibited objects; but soon enough they have turned their backs on the photographer to look at the landscape into which the photographer had sought to insert them. At one moment, they are exhibited natives; at the next, they are subjects scrutinising the representation.

III

A second crucial phase in Pia Arke's artistic project was triggered by a discovery she made in 1995, when she researched the archives of the Explorers Club in New York City. In the collection of Robert E. Peary, the US explorer who in 1909 claimed he had reached the North Pole, Pia found a photo that shocked her: a naked and screaming Inuit woman held for display before the camera by two white men.

The archivist told Pia that the woman was probably suffering from a madness called 'Arctic hysteria.' Judging the picture too disturbing, the Explorers Club denied Pia’s request to reproduce the photograph. But she went on to gather more documentation of Arctic hysteria. This mental disorder, also known as Pibloktoq, was invented in the 1910s and 20s largely based on Peary’s unreliable accounts of Inuit women suffering from fits of rage, uncontrollable behavior and insensitivity to cold. Western psychiatrists, anthropologists and physicians of the period were palpably fascinated by these accounts. Scientific careers were built on the mental and physical abuse of Inuit women. Vanessa Gregory has noted, it was only three years ago that Pibloktoq disappeared from the Diagnostic and Statistical Manual of Mental Disorders, the bible of modern psychiatry. ${ }^{7}$

\footnotetext{
${ }^{7}$ Vanessa Gregory, 'The Unforgettable Pia Arke', Hakai Magazine, 14 February 2017, available at http://bit.ly/2kuTtfM (last accessed on 11 May 2017).
} 
Having traced these women in ethnographic and medical documents, Pia repurposed the material in a portfolio of works. In Arktisk hysteri IV (Arctic Hysteria IV, 1997), for instance, she re-exhibited the Inuit women in various forms of montage, but now beside their masters and as their equals or superiors. We might well envisage the artist as stretching out as far as she could toward the periphery, to give voice to her poor sisters and reclaim human status for them. However, what Pia's work actually reveals is that at the periphery of world history is neither wilderness nor insanity, but a mirror image of Western power. What were once perceived to be representations of natives in a state of mad savagery turn out to be projections of the coloniser's own irrational violence.

Pia saw the limit of world history to be marked by brutalised women - materially and mentally violated, racialised, objectified and dehumanised. Cultural theory has yet to produce a concept to inscribe female figures like these textually into world historiy, or to explain why, in colonial narratives, they so frequently mark borders onto the unknown and dangerous. One achievement of Pia's work is that it serves to powerfully reminder us of this omission and blindness.

Pia posited this female subject not only as a prohibitive limit, however. She also saw her as a horizon figure for the utopic, offering a glimpse of different ways of organising and narrating the world. For a video performance piece titled Arktisk hysteri (Arctic Hysteria, 1996), Pia filmed herself crawling naked and animal-like across a huge enlargement made at Nuugaarsuk using her pinhole camera. The video shows her sniffing and scratching at the image's surface, as though she wants to eat the picture, or disappear into the ice-and-snowcovered landscape. The performance ends with her tearing the photograph into pieces. Pia's practise involved dramas of this kind for a number of works, in which material products of the colonial order were physically destroyed or recycled in unimaginable ways (examples include Legende I-IV [Legend I-IV, 1999], and the video performance Tupilakosaurus: An Interesting 
Study about the Triassic Myth of Kap Stosch, 1999). Such artworks should not just be called counter-representations or counter-narratives. Rather, they are carefully prepared and meticulously documented performances that shake hard at the foundations of the colonial master and the exhibited native so that neither will ever return to their previous positions. What Pia ended up creating in searching for a postcolonial symbology of the Arctic was perhaps not so much a narrative of the Arctic as its performance.

IV

For Stories from Scoresbysund, Pia set herself the task of reclaiming her personal history. This is the third phase I want to mention. To take back her history, she first had to discover how it came about that she was deprived of it, and this involved entering into close combat with world politics. Stories from Scoresbysund is therefore as much a personal as a political book; but it is first and foremost a book filled with wonder, humour and love for a people living at the world's fringes - or rather, at a spot that Europeans placed there.

Pia wanted to recover her own history by returning to her birthplace and the obscure moment of its founding. The colony of Scoresbysund was established by the Danish state in 1924, and populated the following year by Greenlandic families who had been lured or forcibly removed from Ammassalik, a thousand kilometers south. Amongst them were Pia’s maternal grandparents, and it was her dream to represent the founding of the settlement in a form loyal to their perspective.

This was a difficult task, for Scoresbysund's story does not just concern the roughly five hundred individuals living there today. Encapsulated in this story is the history of Danish colonialism, headquartered in Copenhagen. ${ }^{8}$ Incorporated are also the histories of several

\footnotetext{
${ }^{8}$ See Ejnar Mikkelsen, Scoresbysundkolonien, reprint of Tidsskriftet Grønland: 'Scoresbysunds grundlæggelse fortalt af Ejnar Mikkelsen', Tidsskriftet Grønland, vol.37, no.7/8, 1989. This is the most substantial Danish colonial account of the settlement's history.
} 
scientific disciplines: geology, paleontology, ethnography, cartography, meteorology and socalled 'Eskimology', all of which have used Scoresbysund as an operational base. At its deepest level, the story of Scoresbysund embodies the grand, revolting history of Western imperialism.

My contribution to Stories from Scoresbysund was an essay showing how agents of exploration, territorial surveying and cartography created the preconditions for the Scoresbysund settlement. Maps and masterplans of East Greenland were designed in Venice, Amsterdam, Edinburgh, London, Oslo, Brussels and Copenhagen from the seventeenth century onwards. The Danish plan was eventually victorious in the sense that it created facts on the ground of such permanence that the Danes could successfully trump their European competitors in the scramble for sovereignty over this part of the Arctic region.

Yet none of this would have been possible without the enforced support of the East Greenlandic Inuit society. Pia was only too aware that she herself was living evidence of the ambiguous liaison. Her visual and literary narrative in Stories from Scoresbysund constitutes an Arctic counterpart to the Afro-Caribbean project that Aimé Césaire conceived in 1939: his Cahier d'un retour au pays natal (Notebook of a Return to the Native Land), in which a longneglected place of origin is (re)discovered and valorised. ${ }^{9}$ Pia, too, found her origins to be without any cultural purity whatsoever - the 'native land' was the scene of historical crimes. Yet, on the basis of these complex and disavowed roots, Pia managed to reconceive history by recognising the hybrid entanglements it had produced.

The project originated in Pia's bewildered return to her birthplace in the summer of 1997, and her renewed relationship with her brother Ole Brønlund and his family, who lived in the settlement. When, as she wrote me in a letter in the autumn of that year, she 'returned home after 35 years', she felt that this place, while charged with far-reaching historical processes,

\footnotetext{
${ }^{9}$ See Aimé Césaire, Cahier d'un retour au pays natal (1939, ed. Abiola Irele), Ibadan: New Horn Press, 1994.
} 
was marked by a deficit of historical awareness. She wrote of 'a state of historical embarrassment because no one really knows what the history is' ${ }^{10}$ This lack of awareness expressed itself evasively, for example in a reluctance to speak of the first generation's trials and disappointments. Above all, it was negatively demonstrated in the fact that the community possessed no documentation of its own history. Instead, the history of Scoresbysund was to be found outside it: history had 'moved away and dispersed itself in picture archives, scientific studies, diaries, photo albums, attics and basement rooms in Denmark, Paris, New York, Oslo and Stockholm! ${ }^{11}$

Pia wanted to bring this wealth of documentation back to the place where it belonged. She made copies of photographs and documents she had found in European collections, and exhibited this material in Scoresbysund's town hall. These photographic documents formed the basis of the book. Her main aim was to challenge the metropolitan perspective that had determined how this material had been collected and exhibited. The documents presented the dominant view of history that she wanted to dissolve by reinserting the stories of the inhabitants themselves, of the marginalised enablers.

As a consequence, Stories from Scoresbysund presents a compelling picture from below of the world-historical processes that created Scoresbysund. It includes Pia's account of her birth and childhood. She adds the story of her mother along with a portrayal of her maternal grandparents, who had come to the great fjord with dreams of a new life. Linked to these documents are the myriad stories of siblings, cousins, neighbours and others, relayed to Pia orally and in snapshots. In this way, Pia liberated herself and the inhabitants of Scoresbysund from the colonial narrative. The unacknowledged margin became the centre of the world.

\footnotetext{
${ }^{10}$ Undated letter from the artist, c.1997.

${ }^{11}$ Ibid.
} 
Three phases of Pia Arke's artistic career: they add up to a remarkable result. They show an aesthetic imagination at work, transforming historical consciousness. The spectacular images Pia made with her pinhole camera may serve as a model for this process. Spacious enough to fit the artist inside and slow enough to give her time to manipulate the image using her own body as an interfering device, the pinhole camera represents how history and human agency disrupt the relation between object and medium, effectively recreating the world. Every picture bears a ghostly trace of the presence that inserted itself between consciousness and its machinations. The ‘dreamlike quality’ of these images ‘indicates that we are dealing here with an unfinished and maybe unfinishable process’, writes Pia’s brother, the film scholar Erik Gant. $^{12}$

Pia directed a lens toward the colonial periphery that she claimed as her origin. In doing so, she made the camera into an apparatus for mental decolonisation. Inside it, all conceivable pictures of the margins could be processed and accumulated. Suddenly, the borders of the known world were swarming with life - populated by ghosts, monsters, natives, hybrids and hysterics, all engaged in the unmaking of the matrices of knowledge and art. In this sense, too, Pia’s camera exposed the essentially performative nature of representation.

These performances targeted the essential trait of the global narrative, to return to my earlier phrase. One part of this trait is cruelty, generated in the violent embrace between two uneven forces, one coming from the centre, one from the periphery: like the colonising explorer Peary and the nameless Inuit women whom he violated while approaching the North Pole. Another part is resistance and liberation, as the captured subject slips out of the embrace. It is the immeasurable quality of Pia Arke's practise that it managed to stage, in spellbinding imagery, this global encounter between cruelty and liberation.

\footnotetext{
${ }^{12}$ Erik Gant, ‘The “Arke” typical/Pia Arke’, Katalog, vol.8, no.3, Spring 1996, pp.14-17.
} 